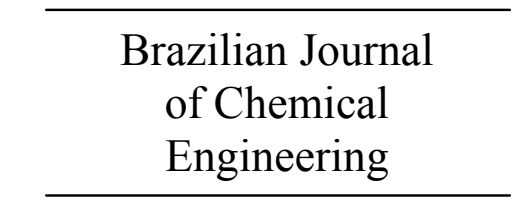

ISSN 0104-6632

Printed in Brazil

www.abeq.org.br/bjche

Vol. 30, No. 02, pp. 355 - 367, April - June, 2013

\title{
PARAMETRIC STUDY OF HYDROGEN PRODUCTION FROM ETHANOL STEAM REFORMING IN A MEMBRANE MICROREACTOR
}

\author{
M. de-Souza, G. M. Zanin and F. F. Moraes* \\ Departamento de Engenharia Química, Universidade Estadual de Maringá, Av. Colombo 5790, \\ Bloco D-90, ZIP 87080-900, Phone: +(55) (44) 3011-4754, Maringá - PR, Brazil. \\ E-mail: marcos@deq.uem.br; gisella@deq.uem.br \\ E-mail: flavio@deq.uem.br
}

(Submitted: February 5, 2012 ; Revised: May 22, 2012 ; Accepted: July 13, 2012)

\begin{abstract}
Microreactors are miniaturized chemical reaction systems, which contain reaction channels with characteristic dimensions in the range of $10-500 \mu \mathrm{m}$. One possible application for microreactors is the conversion of ethanol to hydrogen used in fuel cells to generate electricity. In this paper a rigorous isothermal, steady-state two-dimensional model was developed to simulate the behavior of a membrane microreactor based on the hydrogen yield from ethanol steam reforming. Furthermore, this membrane microreactor is compared to a membraneless microreactor. A potential advantage of the membrane microreactor is the fact that both ethanol steam reforming and the separation of hydrogen by a permselective membrane occur in one single microdevice. The simulation results for steam reforming yields are in agreement with experimental data found in the literature. The results show that the membrane microreactorpermits a hydrogen yield of up to 0.833 which is more than twice that generated by the membraneless reactor. More than $80 \%$ of the generated hydrogen permeates through the membrane and, due to its high selectivity, the membrane microreactor delivers high-purity hydrogen to the fuel cell.

Keywords: Bioethanol; Microchannel reactor; Modeling; PEM fuel cells; Portable devices.
\end{abstract}

\section{INTRODUCTION}

The fast evolution of multifunctional portable devices leads to increasing consumption of electrical power, and providing sufficiently long-lasting power sources for portable devices (such as laptops and cell phones) becomes more and more challenging, even when a modern lithium-ion battery is used. The higher power consumption contributes to environmental pollution arising from the mass disposal of expended batteries. Long-life batteries offering high efficiency and reduced environmental impact are therefore in demand. Hydrogen-based proton exchange membrane fuel cells (PEMFCs) seem promising due to their high energy efficiency and clean exhaust gases. Because of their small size, light weight, fast start-up, and rapid response, PEM fuel cells are suitable for portable power sources, capable of delivering power in the 1-100 W range (Delsman, 2005; Hu et al., 2003; Palo et al., 2002). Three types of small PEM fuel cells systems have been proposed: systems that use stored hydrogen, direct methanol or ethanol systems and on-board reforming systems (Kawamura et al., 2006). Hydrogen storage methods are currently limited by their inability to meet the practical requirements of safety, weight, and cost considerations (Winter, 2009). Despite the advantage of room-temperature operation, direct methanol or

*To whom correspondence should be addressed 
ethanol systemsoffer only relatively low power density due to methanol/ethanol crossover through the polymer electrolyte membrane and the low reaction rate of fuel oxidation over the anode electrocatalyst. On the other hand, on-board reforming systems generate electric energy in fuel cells from hydrogen by steam reforming, for example, from ethanol (Aicher et al., 2009; Aravamudhan et al., 2005; Deshmukh and Vlachos, 2005; Palo et al., 2002; Sordi et al.,2009; Yao et al., 2006).

We propose to explore the use of a microchannel reactor to produce hydrogen by the reaction of ethanol with water. The schematic of our proposed fuel processor is shown in Fig. 1 (a). It should have the following three main components: (1) catalytic oxidation of the exhaust gases produced in the ethanol steam reforming channel for providing the energy required by the reforming reaction; (2) ethanol steam reforming with particles of $\mathrm{Ni} / \mathrm{Al}_{2} \mathrm{O}_{3}$ (catalyst) and a palladium micromembrane for hydrogen separation; (3) PEMFC, which consumes the produced hydrogen as it crosses the membrane. This paper will focus on the modeling of a palladium based membrane microreactor for hydrogen separation as well as steam reforming of the ethanol in a fixed bed microchannel (shown in Fig. 1 (b)).

\section{(a)}

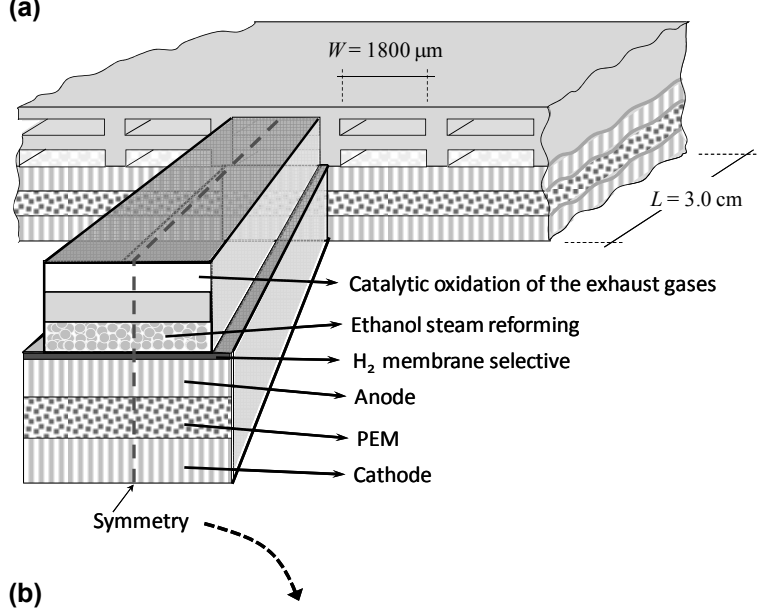

(b)

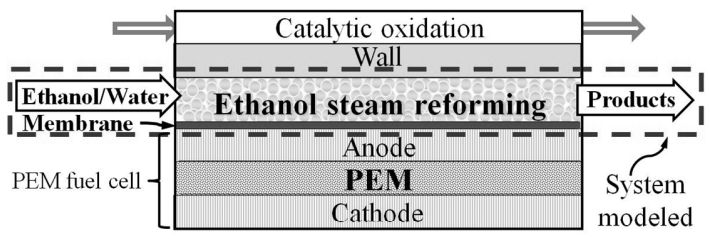

Figure 1: Schematic representation of the micro-fuel processor: (a) 3-D representation, (b) 2-D symmetry indicating the system modeled.

\section{Ethanol Steam Reforming}

Ethanol steam reforming is the cheapest and most efficient way to produce hydrogen from biomass. Both reactants (water and ethanol) contain $\mathrm{H}$ atoms which contribute to the hydrogen yield and, furthermore, ethanol is nontoxic and easy to store and transport (Fatsikostas and Verykios, 2004; Iulianelli et al., 2009; Kawamura et al., 2006; Mariño et al., 2001; Sun et al., 2005). This technology is particularly interesting for a country such as Brazil, which is one of the largest ethanol producers and exporters in the world and where ethanol from sugarcane is produced at extremely competitive prices. Its daily 2006 production exceeded 300000 barrels (Hotza and Costa, 2008). Stoichiometrically, the overall ethanol steam reforming reaction can be represented as follows:

$$
\mathrm{C}_{2} \mathrm{H}_{5} \mathrm{OH}+3 \mathrm{H}_{2} \mathrm{O} \rightleftarrows 2 \mathrm{CO}_{2}+6 \mathrm{H}_{2} \quad \text { (Reaction 1) }
$$

However, there are several reaction pathways that can occur in the ethanol steam reforming process, depending on the catalyst and the operating conditions. Therefore, the selectivity for hydrogen is affected by many undesirable side reactions (Haryanto et al., 2005; Vaidya and Rodrigues, 2006). Ni catalysts with alumina support have relatively low cost and have been reported to be very active and selective for ethanol steam reforming (Fatsikostas and Verykios, 2004; Mariño et al., 2001; Therdthianwong et al., 2001). Comas et al. (2004b) have investigated ethanol steam reforming based on $\mathrm{Ni} / \mathrm{Al}_{2} \mathrm{O}_{3}$ catalyst. The reactor was made with a Pyrex glass tube of $12 \mathrm{~mm}$ inner diameter. The experiments were performed under the following conditions: catalytic mass: $0.105-0.840 \mathrm{~g}$; temperature: $573-773 \mathrm{~K}$; total feed rate: $210 \mathrm{ml} / \mathrm{min}$; ethanol molar fraction: 0.017 ; water/ethanol molar ratio: 1-6. They proposed that good steam reforming performance is established at a temperature of $773 \mathrm{~K}$ and then occurs according to the reaction $\mathrm{C}_{2} \mathrm{H}_{5} \mathrm{OH}+\mathrm{H}_{2} \mathrm{O} \rightarrow \mathrm{CH}_{4}+\mathrm{CO}_{2}+2 \mathrm{H}_{2}$ followed by methane steam reforming. At this temperature $(773 \mathrm{~K})$ they used a space time of up to $4 \mathrm{~g}_{\text {cat }} \mathrm{min} / \mathrm{l}\left(8.95 \times 10^{5} \mathrm{~g}_{\mathrm{cat}} \mathrm{s} / \mathrm{mol}_{\mathrm{EtOH}}\right)$ and a water/ ethanol ratio of 3.3. The main products obtained were $\mathrm{CO}, \mathrm{CO}_{2}, \mathrm{CH}_{4}$ and $\mathrm{H}_{2}$.

Nowadays, it is known that the $\mathrm{CO}$ concentration in the hydrogen flow is crucial as it leads to deactivation of the Pt electrode of the PEM fuel cell. Thus, any CO concentration above $20 \mathrm{ppm}$ cannot be tolerated in the hydrogen flow (Aicher et al., 2009; Karnik et al., 2003; Klouz et al., 2002). Almost all 
the catalysts used for ethanol steam reforming produce $\mathrm{CO}$ at concentrations limited by thermodynamic balance, and the reforming process alone is insufficient to reach the allowed level of CO. Thus, purification methods are necessary to remove $\mathrm{CO}$ present in the product flow of the reformer (Sordi et al., 2009), such as preferential oxidation of the carbon monoxide in a PrOx reactor, pressure swing adsorption, cryogenic distillation or membrane technology in which $\sim 99.9 \%$ pure of hydrogen can be produced.

\section{Microreactors}

The use of microreactors for in-situ and ondemand chemical processing is gaining increasing importance in the chemical industry. Microreactors have characteristic properties, like a high surface to volume ratio, the use of small amounts of chemicals, high heat and mass transfer rates, and short residence times that make these devices a research topic of high interest. Microreactors have been proposed for various applications, such as intrinsic kinetic studies, catalyst screening, fine-chemical synthesis, and in launching fuel cells systems for portable power generation (Hu et al., 2003; Löwe and Ehrfeld, 1999; Wörz et al., 2001). The microreformer fuel cell combination has the advantage of avoiding the tedious charging cycles needed by conventional rechargeable lithium-ion batteries. Also, the energy storage density per unit weight of this system is higher than that of batteries (Palo et al., 2002; Pattekar et al., 2001; Terazaki et al., 2005). Thus, less frequent recharging in terms of refilling with ethanol fuel is necessary. Membrane microreactors are an important class of microreactors that combine reaction and separation in one single device. Thus, for example, a thin palladium membrane can be included which separates hydrogen from the reformate gas mixture (Alfadhel and Kothare, 2005; Assaf et al., 1998; Karnik et al., 2003). Assaf et al. (1998) modeled the methane steam reforming in an isothermal membrane reactor and concluded that the membrane reactor, besides providing purified hydrogen still presents a higher methane conversion yield than the conventional fixed-bed reactor. This work presents a two-dimensional mathematical model of an isothermal membrane microreactor operating under steady-state conditions for use as a source of pure hydrogen for a PEM fuel cell from ethanol steam reforming catalyzed by $\mathrm{Ni} / \mathrm{Al}_{2} \mathrm{O}_{3}$. The model aims at simulating the behavior of a membrane microreactor, so the yield improvements in relation to a membraneless fixed-bed microreactor are compared and discussed. The complete membrane microreformer fuel cell unit can be considered to be a promising alternative to conventional sources of energy due to its ability to provide an uninterruptible power supply as long as ethanol and water are provided.

\section{MODEL DEVELOPMENT}

For ethanol steam reforming, a catalytic fixed-bed microreactor is fed with a gas mixture of ethanol and water in a water/ethanol molar ratio of 3.3. The reactor consists of several microchannels (in sufficient quantity as to be able to assume that the system behaves as the bidimensional system as shown in Fig. 2) with a height of $\mathrm{H}=5 \times 10^{-4} \mathrm{~m}$, width of $\mathrm{W}=1.8 \times 10^{-3} \mathrm{~m}$ and length of $\mathrm{L}=3.0 \times 10^{-2} \mathrm{~m}$ The computational domain employed in this study consists of a single rectangular channel (Figure 2) in steady-state conditions, isothermal operation and the fluid is assumed to be an ideal gas mixture that follows Dalton's law. The microreactors allow fast heat transfer due to their thin wall thicknesses and thus the reaction is maintained at an optimal operating temperature (Löwe \& Ehrfeld, 1999). The energy required for performing an endothermic reaction can be supplied via an exothermic reaction, whose coupling can be achieved by operating endothermic and exothermic reactions in parallel microchannels (Deshmukh \& Vlachos, 2005). The model investigated in this study is a membrane microreactor, where a hydrogen-permselective membrane substitutes one of the solid walls of the microchannel. We studied space times $\left(\tau=\mathrm{w}_{\text {cat }} / \mathrm{Fe}_{0}\right)$ ranging from $0.75 \times 10^{5}$ to $2.24 \times 10^{5} \quad \mathrm{~g}_{\text {cat }} \mathrm{s} / \mathrm{mol}$ (corresponding to 0.335 to $1 \mathrm{~g}_{\text {cat }} \mathrm{min} / \mathrm{l}$ ).

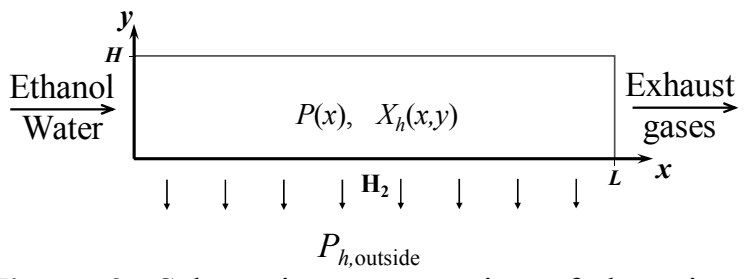

Figure 2: Schematic representation of the microchannel reactor modeled.

\section{Ethanol Steam Reforming Kinetics}

The reaction pathway proposed for ethanol steam reforming catalyzed by $\mathrm{Ni} / \mathrm{Al}_{2} \mathrm{O}_{3}$ was based on the work of Haryanto et al. (2005), Sun et al. (2005), Comas et al. (2004a) and Fatsikostas and Verykios (2004). The reaction pathway includes ethanol 
decomposition into methane, carbon monoxide and hydrogen (Reaction 2), the water gas shift WGS reaction (Reaction 3) and methane steam reforming (Reactions 4 and Reaction 5).

$\mathrm{C}_{2} \mathrm{H}_{5} \mathrm{OH} \rightarrow \mathrm{CH}_{4}+\mathrm{CO}+\mathrm{H}_{2}$

(Reaction 2)

$\mathrm{CO}+\mathrm{H}_{2} \mathrm{O} \rightleftarrows \mathrm{CO}_{2}+\mathrm{H}_{2}$

(Reaction 3)

$\mathrm{CH}_{4}+\mathrm{H}_{2} \mathrm{O} \rightleftarrows \mathrm{CO}+3 \mathrm{H}_{2}$

(Reaction 4)

$\mathrm{CH}_{4}+2 \mathrm{H}_{2} \mathrm{O} \rightleftarrows \mathrm{CO}_{2}+4 \mathrm{H}_{2}$

(Reaction 5)

Sun et al. (2005) proposed the following rate expression for ethanol consumption in the reforming process catalyzed by $\mathrm{Ni} / \mathrm{Al}_{2} \mathrm{O}_{3}$ :

$\mathrm{r}_{2}=\mathrm{k}_{2} \mathrm{PX}_{\mathrm{e}}$

Kinetic expressions for Reactions 3, 4 and 5 are given by $\mathrm{Xu}$ and Froment (1989). These expressions are reported in Equations (2), (3) and (4), respectively:

$$
r_{3}=\frac{k_{3} P}{X_{h} \operatorname{den}^{2}}\left[X_{m} X_{w}-\frac{X_{d} X_{h}}{K_{3}}\right]
$$

$$
\mathrm{r}_{4}=\frac{\mathrm{k}_{4}}{\mathrm{X}_{\mathrm{h}}^{2.5} \operatorname{den}^{2} \sqrt{\mathrm{P}}}\left[\mathrm{X}_{\mathrm{me}} \mathrm{X}_{\mathrm{w}}-\frac{\mathrm{X}_{\mathrm{m}} \mathrm{X}_{\mathrm{h}}^{3} \mathrm{P}^{2}}{\mathrm{~K}_{4}}\right]
$$

$$
\mathrm{r}_{5}=\frac{\mathrm{k}_{5}}{\mathrm{X}_{\mathrm{h}}^{3.5} \operatorname{den}^{2} \sqrt{\mathrm{P}}}\left[\mathrm{X}_{\mathrm{me}} \mathrm{X}_{\mathrm{w}}^{2}-\frac{\mathrm{X}_{\mathrm{d}} \mathrm{X}_{\mathrm{h}}^{4} \mathrm{P}^{2}}{\mathrm{~K}_{5}}\right]
$$

where den is

$$
\begin{aligned}
\operatorname{den}= & 1+P\left(K_{m} X_{m}+K_{h} X_{h}+K_{m e} X_{m e}\right) \\
& +\frac{K_{\mathrm{w}} X_{w}}{X_{h}}
\end{aligned}
$$

The reactions rates are given in $\mathrm{mol} \mathrm{g}_{\mathrm{cat}}{ }^{-1} \mathrm{~s}^{-1}$. The subscripts $\mathrm{e}, \mathrm{w}, \mathrm{m}, \mathrm{me}, \mathrm{d}$ and $\mathrm{h}$ indicate the components: $\mathrm{C}_{2} \mathrm{H}_{5} \mathrm{OH}$ (ethanol), $\mathrm{H}_{2} \mathrm{O}, \mathrm{CO}, \mathrm{CH}_{4}, \mathrm{CO}_{2}$ and $\mathrm{H}_{2}$, respectively (these subscripts will sometimes be denoted generically by the indexes $\mathrm{i}$ or $\mathrm{k}$ ); $\mathrm{X}_{\mathrm{i}}$ is the gas phase mole fraction of component $\mathrm{i} ; \mathrm{k}_{\mathrm{j}}$ denotes the reaction rate constant and $K_{j}$ the equilibrium constant of the $\mathrm{j}^{\text {th }}$ reaction. The kinetic

\begin{tabular}{|c|c|c|c|}
\hline Symbol & Expression* & Value & $=773 \mathrm{~K}$ \\
\hline $\mathrm{k}_{2}{ }^{\mathrm{a}}$ & $\frac{4.55 \times 10^{-5}}{\mathrm{~T}} \exp \left(-\frac{2030}{\mathrm{~T}}\right)$ & $4.26 \times 10^{-9}$ & $\mathrm{~mol} \mathrm{~Pa} a^{-1} \mathrm{~g}_{\mathrm{cat}}{ }^{-1} \mathrm{~s}^{-1}$ \\
\hline $\mathrm{k}_{3}{ }^{\mathrm{b}}$ & $5.43 \times 10^{-3} \exp \left(\frac{-8074.33}{\mathrm{~T}}\right)$ & $1.58 \times 10^{-7}$ & $\mathrm{~mol} \mathrm{~Pa}{ }^{-1} \mathrm{~g}_{\text {cat }}{ }^{-1} \mathrm{~s}^{-1}$ \\
\hline $\mathrm{k}_{4}{ }^{\mathrm{b}}$ & $3.711 \times 10^{14} \exp \left(\frac{-28879}{\mathrm{~T}}\right)$ & $2.21 \times 10^{-2}$ & $\mathrm{~mol} \mathrm{~Pa}{ }^{0.5} \mathrm{~g}_{\text {cat }}{ }^{-1} \mathrm{~s}^{-1}$ \\
\hline $\mathrm{k}_{5}{ }^{\mathrm{b}}$ & $8.960 \times 10^{13} \exp \left(\frac{-29336.1}{T}\right)$ & $2.95 \times 10^{-3}$ & $\mathrm{~mol} \mathrm{~Pa}{ }^{0.5} \mathrm{~g}_{\text {cat }}{ }^{-1} \mathrm{~s}^{-1}$ \\
\hline $\mathrm{K}_{3}^{\mathrm{b}}$ & $\exp \left(\frac{4400}{T}-4.036\right)$ & 5.239 & \\
\hline $\mathrm{K}_{4}{ }^{\mathrm{b}}$ & $1 \times 10^{10} \exp \left(\frac{-26830}{\mathrm{~T}}+30.114\right)$ & $1.01 \times 10^{8}$ & $\mathrm{~Pa}^{2}$ \\
\hline $\mathrm{K}_{5}{ }^{\mathrm{b}}$ & $\mathrm{K}_{3} \mathrm{~K}_{4}$ & $5.29 \times 10^{8}$ & $\mathrm{~Pa}^{2}$ \\
\hline $\mathrm{K}_{\mathrm{m}}{ }^{\mathrm{b}}$ & $8.230 \times 10^{-10} \exp \left(\frac{8497.71}{\mathrm{~T}}\right)$ & $4.89 \times 10^{-5}$ & $\mathrm{~Pa}^{-1}$ \\
\hline $\mathrm{K}_{\mathrm{me}}^{\mathrm{b}}$ & $6.640 \times 10^{-9} \exp \left(\frac{4604.28}{\mathrm{~T}}\right)$ & $2.56 \times 10^{-6}$ & $\mathrm{~Pa}^{-1}$ \\
\hline $\mathrm{K}_{\mathrm{h}}^{\mathrm{b}}$ & $6.120 \times 10^{-14} \exp \left(\frac{9971.13}{\mathrm{~T}}\right)$ & $2.45 \times 10^{-8}$ & $\mathrm{~Pa}^{-1}$ \\
\hline $\mathrm{K}_{\mathrm{w}}^{\mathrm{b}}$ & $1.770 \times 10^{5} \exp \left(\frac{-10666.35}{\mathrm{~T}}\right)$ & $1.80 \times 10^{-1}$ & \\
\hline
\end{tabular}
parameters for ethanol steam reforming with $\mathrm{Ni} / \mathrm{Al}_{2} \mathrm{O}_{3}$ at the temperature of $773 \mathrm{~K}$ are given at Table 1.

Table 1: Kinetic parameters for the ethanol steam reforming process over $\mathbf{N i} / \mathrm{Al}_{2} \mathrm{O}_{3}$.

* Temperature in Kelvin

${ }^{\text {a }}$ Taken from Sun et al. (2005)

${ }^{\mathrm{b}}$ Taken from Xu and Froment (1989) 
In this work, these kinetic expressions were used for a parametric study with the kinetic parameters of Sun et al. (2005) and Xu and Froment (1989) given in Table 1.

\section{Models and Boundary Conditions}

According to Pattekar and Kothare (2002), a rigorous partial differential equation for modeling mass, momentum and energy balances is better suited for microreaction systems than empirical approaches which are often applied for modelling conventional large-scale processes. Thus, transport phenomena in an isothermal microchannel reformer can be described by the conservation equations of mass and momentum leading to a set of non-linear partial differential equations. The microchannel filled with catalyst particles forms a porous medium and thus Darcy's law will be considered for the flow across the micro-packed bed:

$$
\mathbf{u}=(\mathrm{u}, \mathrm{v})=-\frac{\mathrm{K}_{\mathrm{p}}}{\mu} \nabla \mathrm{P}
$$

where $\mathbf{u}$ is the fluid flow velocity vector; $\mathrm{P}$ denotes the pressure; $\mu$ denotes the dynamic viscosity of the fluid and $\mathrm{K}_{\mathrm{p}}$ the permeability of the porous media, which can be estimated by the expression:

$$
\mathrm{K}_{\mathrm{p}}=\frac{\mathrm{d}_{\mathrm{p}}^{2} \varepsilon^{3}}{150(1-\varepsilon)^{2}}
$$

in which $\varepsilon$ is the porosity of the bed and $\mathrm{d}_{\mathrm{p}}$ is the catalyst particle diameter. This method of calculating $\mathrm{K}_{\mathrm{p}}$ provides an estimation of the actual value varying according to the catalyst packing conditions (Pattekar and Kothare, 2004). The steady-state mass conservation balance combined with Eq. (6), the molar equation of continuity and the ideal gas law leads to:

$$
\nabla \cdot\left(-\frac{\mathrm{P}}{\mathrm{R}_{\mathrm{g}} \mathrm{T}} \frac{\mathrm{K}_{\mathrm{p}}}{\mu} \nabla \mathrm{P}\right)=\sum_{\mathrm{i}=1}^{6} \sum_{\mathrm{j}=2}^{5} v_{\mathrm{ij}} \mathrm{r}_{\mathrm{j}}=2\left(\mathrm{r}_{2}+\mathrm{r}_{4}+\mathrm{r}_{5}\right)
$$

where $\mathrm{R}_{\mathrm{g}}$ is the universal gas constant, $\mathrm{T}$ the temperature; i represents any of $\mathrm{C}_{2} \mathrm{H}_{5} \mathrm{OH}, \mathrm{H}_{2} \mathrm{O}, \mathrm{CO}$, $\mathrm{CH}_{4}, \mathrm{CO}_{2}$ and $\mathrm{H}_{2} ; \mathrm{j}$ indicates the chemical reaction (Reaction 2, 3, 4 or 5) and $v_{\mathrm{ij}}$ is the stoichiometric coefficient of component $i$ in the $j^{\text {th }}$ reaction. The local dynamic viscosity is established based on the Chapman-Enskog theory for multi-component gas mixtures at low density (Bird et al., 2004):

$$
\mu=\sum_{\mathrm{i}=1}^{5} \frac{\mathrm{X}_{\mathrm{i}} \mu_{\mathrm{i}}}{\sum_{\mathrm{k}=1}^{5}\left(\mathrm{X}_{\mathrm{k}} \Phi_{\mathrm{ik}}\right)}
$$

with the Chapman-Enskog parameter:

$$
\Phi_{\mathrm{ik}}=\frac{1}{\sqrt{8}}\left(1+\frac{\mathrm{M}_{\mathrm{i}}}{\mathrm{M}_{\mathrm{k}}}\right)^{-1 / 2}\left[1+\left(\frac{\mu_{\mathrm{i}}}{\mu_{\mathrm{k}}}\right)^{1 / 2}\left(\frac{\mathrm{M}_{\mathrm{k}}}{\mathrm{M}_{\mathrm{i}}}\right)^{1 / 4}\right]^{2}
$$

where $M_{i}$ denotes the molecular weight and $\mu_{i}$ the

\begin{tabular}{|c|c|}
\hline Lennard-Jones collision diameter & $\sigma_{\mathrm{i}}$ (angstroms) \\
\hline Ethanol & 4.455 \\
\hline $\mathrm{H}_{2} \mathrm{O}$ & 2.655 \\
\hline $\mathrm{CH}_{4}$ & 3.882 \\
\hline $\mathrm{CO}$ & 3.590 \\
\hline $\mathrm{CO}_{2}$ & 3.996 \\
\hline $\mathrm{H}_{2}$ & 2.968 \\
\hline $\begin{array}{l}\text { Maximum attractive energy } \\
\text { between two molecules }\end{array}$ & $\mathbf{c}_{\mathbf{i}} / \mathbf{K}$ (Kelvin) \\
\hline Ethanol & 391.0 \\
\hline $\mathrm{H}_{2} \mathrm{O}$ & 363.0 \\
\hline $\mathrm{CH}_{4}$ & 136.5 \\
\hline $\mathrm{CO}$ & 110.3 \\
\hline $\mathrm{CO}_{2}$ & 190.0 \\
\hline $\mathrm{H}_{2}$ & 33.3 \\
\hline Dynamic viscosity at $773 \mathrm{~K}$ & $\mu_{\mathrm{i}}\left(\mathrm{g} \mathrm{m}^{-1} \mathrm{~s}^{-1}\right)$ \\
\hline Ethanol & 0.0213 \\
\hline $\mathrm{H}_{2} \mathrm{O}$ & 0.0275 \\
\hline $\mathrm{CH}_{4}$ & 0.0237 \\
\hline $\mathrm{CO}$ & 0.0345 \\
\hline $\mathrm{CO}_{2}$ & 0.0335 \\
\hline $\mathrm{H}_{2}$ & 0.0166 \\
\hline
\end{tabular}
dynamic viscosity of an individual component. The values of $\mu_{\mathrm{i}}$ for the substances used in this work are given at Table 2 .

Table 2: Properties of the species (Perry et al., 1997).

The boundary conditions are described as follows:

At the microchannel inlet boundary $(x=0)$ :

$\mathrm{u}_{\mathrm{o}}=-\frac{\mathrm{K}_{\mathrm{p}}}{\mu} \frac{\partial \mathrm{P}}{\partial \mathrm{x}}$, and $\mathrm{v}=0,0 \leq \mathrm{y} \leq \mathrm{H}$

At the microchannel outlet boundary $(\mathrm{x}=\mathrm{L})$ :

$\mathrm{P}=\mathrm{P}_{\text {out }}, 0 \leq \mathrm{y} \leq \mathrm{H}$

At the microchannel superior boundary $(y=H)$ :

$\frac{\partial \mathrm{P}}{\partial \mathrm{y}}=0,0 \leq \mathrm{x} \leq \mathrm{L}$ 
At the microchannel inferior boundary $(\mathrm{y}=0)$ :

$\mathrm{v}_{\mathrm{p}}=-\frac{\mathrm{k}_{\mathrm{p}}}{\mu} \frac{\partial \mathrm{P}}{\partial \mathrm{y}}, 0 \leq \mathrm{x} \leq \mathrm{L}$,

This last condition is due to permeation through the permselective membrane, in which $\mathrm{v}_{\mathrm{p}}(\mathrm{m} / \mathrm{s})$ is the velocity of the fluid as it diffuses through the membrane (drift velocity) and $k_{p}$ is the permeability of the membrane. Alfadhel and Kothare (2005) and Karnik et al. (2003) defined $\mathrm{v}_{\mathrm{p}}$ as follows:

$$
\mathrm{v}_{\mathrm{p}}=\frac{\mathrm{k}_{\mathrm{p}}}{\delta} \exp \left(\frac{-\mathrm{E}}{\mathrm{R}_{\mathrm{g}} \mathrm{T}}\right) \mathrm{R}_{\mathrm{g}}\left(\frac{\left(\mathrm{PX}_{\mathrm{h}}\right)^{\mathrm{q}}-\mathrm{P}_{\mathrm{h}, \text { outside }}^{\mathrm{q}}}{\mathrm{PX}_{\mathrm{h}}}\right)
$$

where $\delta$ is the membrane thickness and $\mathrm{P}_{\mathrm{h}, \text { outside }}$ is the partial pressure of the hydrogen outside of the membrane. Karnik et al. (2003) evaluated a $0.2 \mu \mathrm{m}$ thick Pd membrane and obtained $\mathrm{E}=4077.2 \mathrm{~J} / \mathrm{mol}$, $\mathrm{k}_{\mathrm{p}}=4.15 \times 10^{-6} \mathrm{~mol} \mathrm{~K} /\left(\mathrm{m} \mathrm{Pa}^{0.489} \mathrm{~s}\right)$ and $\mathrm{q}=0.489$. Because the hydrogen that crosses the membrane is immediately consumed by PEMFC, it is assumed that $\mathrm{P}_{\mathrm{h}, \text { outside }}<<\mathrm{PX}_{\mathrm{h}}$; then:

$$
\mathrm{v}_{\mathrm{p}}=\frac{3.45 \times 10^{-5}}{\left.(\mathrm{PX})_{\mathrm{h}}\right)^{0.511}} \exp \left(-\frac{490.4}{\mathrm{~T}}\right)
$$

The steady-state mass conservation equation for the individual gas-phase species is

$$
\begin{aligned}
& \nabla \cdot\left[\mathscr{D}_{\text {ef }, \mathrm{i}} \nabla\left(-\frac{\mathrm{P}}{\mathrm{R}_{\mathrm{g}} \mathrm{T}} \mathrm{X}_{\mathrm{i}}\right)+\mathbf{u} \frac{\mathrm{P}}{\mathrm{R}_{\mathrm{g}} \mathrm{T}} \mathrm{X}_{\mathrm{i}}\right]= \\
& \rho_{\text {cat }}(1-\varepsilon) \sum_{\mathrm{j}=2}^{5} v_{\mathrm{ij}} \mathrm{r}_{\mathrm{j}}, \quad \mathrm{i}=\mathrm{e}, \mathrm{w}, \ldots, \mathrm{h}
\end{aligned}
$$

where $\rho_{\text {cat }}$ is the catalyst mass per unit of volume, $\varepsilon$ is the porosity of the media and $\mathscr{D}_{\text {ef }, \mathrm{i}}=\mathscr{D}_{\mathrm{i}} \varepsilon^{3 / 2}$ is the effective concentration-driven diffusion coefficient of the specie $i$, in which $\mathscr{D}_{\mathrm{i}}$ is expressed in terms of binary diffusion coefficients:

$$
\mathcal{D}_{\mathrm{i}}=\frac{1-\mathrm{X}_{\mathrm{i}}}{\sum_{\mathrm{k}=1, \mathrm{k} \neq \mathrm{i}}^{\mathrm{n}} \frac{\mathrm{X}_{\mathrm{i}}}{\mathrm{D}_{\mathrm{ik}}}}
$$

The $D_{i k}$ values are obtained from the ChapmanEnskog theory:
$\mathrm{D}_{\mathrm{ik}}=5.9543 \times 10^{-4} \frac{\sqrt{\mathrm{T}^{3}\left(\frac{1}{\mathrm{M}_{\mathrm{i}}}+\frac{1}{\mathrm{M}_{\mathrm{k}}}\right)}}{\mathrm{P \sigma}_{\mathrm{ik}}^{2} \Omega_{\mathrm{ik}}}$

in which $\sigma_{\mathrm{ik}}$ and $\Omega_{\mathrm{ik}}$ are, respectively, the LennardJones collision diameter and collision integral between one molecule of $\mathrm{i}$ and one molecule of $\mathrm{k}$. This equation is given by Bird et al. (2004). In this work the constant in Eq. (15) was recalculated to give $D_{i k}$ in the units of $\mathrm{m}^{2} / \mathrm{s}$, and, for this, the pressure, in $\mathrm{Pa}$, and $\mathrm{M}_{\mathrm{i}}$ in $\mathrm{kg} / \mathrm{mol}$, were used. The collision diameter is obtained from $\sigma_{\mathrm{ik}}=1 / 2\left(\sigma_{\mathrm{i}}+\sigma_{\mathrm{k}}\right)$ and $\Omega_{\mathrm{ik}}$ is taken from Neufeld et al. (1972).

$$
\begin{aligned}
& \Omega_{\mathrm{ik}}=\frac{1.06036}{\tau_{\mathrm{ik}}^{0.15610}}+\frac{0.19300}{\exp \left(0.47635 \tau_{\mathrm{ik}}\right)}+ \\
& \frac{1.03587}{\exp \left(1.52996 \tau_{\mathrm{ik}}\right)}+\frac{1.76474}{\exp \left(3.89411 \tau_{\mathrm{ik}}\right)}
\end{aligned}
$$

in which $\tau_{\mathrm{ik}}=\mathrm{KT} / \varepsilon_{\mathrm{ik}}$ is the dimensionless temperature, where $\mathrm{K}$ is the Boltzmann constant and $\varepsilon_{\mathrm{ik}}=\sqrt{\varepsilon_{\mathrm{i}} \varepsilon_{\mathrm{k}}}$ is the maximum attractive energy between one molecule of $\mathrm{i}$ and one molecule of $\mathrm{k}$. The values of $\sigma_{\mathrm{i}}$ and $\varepsilon_{\mathrm{i}} / \mathrm{K}$ for the substances used in this work are given in Table 2.

The order of magnitude values of the effective mass diffusivity are about $5 \times 10^{-5}$ for all the species. The Peclet number, $\mathrm{Pe}=\mathrm{u}_{0} \mathrm{~L} / \mathcal{D}_{e f, i}$, was calculated to be larger than 10 for the current simulation conditions, thereby indicating that diffusion effects are minor or even negligible compared to convective effects. Therefore, the more rigorous MaxwellStefan formulation is not applied, which is used for diffusion-dominated flows. Furthermore, its computational cost is considerably higher. The boundary conditions associated with mass transport within the microchannels are as follows.

At the microchannel inlet boundary, $(\mathrm{x}=0)$ :

$\mathrm{X}_{\mathrm{i}}=\mathrm{X}_{\mathrm{io}}, \quad 0 \leq \mathrm{y} \leq \mathrm{H}$

At the microchannel outlet boundary, $(\mathrm{x}=\mathrm{L})$ :

$\mathrm{N}_{\mathrm{i}}=\mathrm{u} \frac{\mathrm{PX_{i }}}{\mathrm{R}_{\mathrm{g}} \mathrm{T}}, 0 \leq \mathrm{y} \leq \mathrm{H}$,

where $\mathrm{N}_{\mathrm{i}}$ is the flux of the specie $\mathrm{i}$ in the normal direction to the boundary, given in $\mathrm{mol} /\left(\mathrm{m}^{2} \mathrm{~s}\right)$. 
At the microchannel superior boundary, $y=H$ ):

$$
\frac{\partial \mathrm{X}_{\mathrm{i}}}{\partial \mathrm{y}}=0, \quad 0 \leq \mathrm{x} \leq \mathrm{L}
$$

At the microchannel inferior boundary $(y=0)$, due to selective permeation of the hydrogen through the membrane:

$$
\left.\mathrm{N}_{\mathrm{i}}\right|_{\mathrm{i} \neq \mathrm{h}}=0 \text { and } \mathrm{N}_{\mathrm{h}}=\mathrm{v}_{\mathrm{p}} \frac{\mathrm{PX}}{\mathrm{R}_{\mathrm{g}} \mathrm{T}}, 0 \leq \mathrm{x} \leq \mathrm{L}
$$

In other words, at $\mathrm{y}=0$,

$$
\mathrm{N}_{\mathrm{h}}=\frac{4.15 \times 10^{-6}}{\delta \mathrm{T}} \exp \left(-\frac{490.4}{\mathrm{~T}}\right)\left(\mathrm{PX}_{\mathrm{h}}\right)^{0.489}
$$

\section{RESULTS AND DISCUSSION}

For a mesh with 2418 nodes and 4660 elements, the computational times ranged between 15 and 20 CPU minutes on a personal computer $(1.8 \mathrm{GHz}$ AMD, 1 GB RAM). The parameters used in this modeling are given at Table 3 . Bed porosity was estimated by the relationship given by Dixon (1988): $\varepsilon=0.4+0.05\left(\mathrm{~d}_{\mathrm{p}} / \mathrm{H}\right)+0.412\left(\mathrm{~d}_{\mathrm{p}} / \mathrm{H}\right)^{2}$. The packing of the reactor is normally looser near the reactor wall and velocity gradients can be observed there. As a rough guide, the deviation from the flat profile of velocity assumed in plug flow is not more than $20 \%$, provided that the tube diameter is at least $30 \times$ the particle diameter (Trimm, 1980). To guarantee that the flow pattern in the membraneless reactor was plug flow, we established that the smallest dimension of the microchannel should be 50 times greater than the catalyst bed particle diameter; this leads to $\mathrm{d}_{\mathrm{p}}=1 \times 10^{-5} \mathrm{~m}$ because the microchannel had $\mathrm{H}=5 \times 10^{-4} \mathrm{~m}$. Many published papers that used metal catalysts supported on alumina have catalyst densities in the range of $1-2 \times 10^{6} \mathrm{~g} / \mathrm{cm}^{3}$ (Falco and Gallucci, 2010; Kim et al., 2005; Kawamura et al., 2006; Wang and Rodrigues, 2005; Lee et al., 2006). The value of the catalyst density used in this work $\left(\rho_{\text {cat }}=1.35 \times 10^{6} \mathrm{~g} / \mathrm{cm}^{3}\right)$ was adjusted to obtain a space time equivalent to that used by Comas et al. (2004b) in his experimental measurements. Therefore, we have chosen the appropriate catalyst density to be able to compare our modeling results with the experimental data of Comas et al. (2004b).

A numerical problem arises from the initial value of hydrogen in the feedstock, which generates a division by zero in the reaction rate equations. This problem has been sorted out by using a very small value for the mole fraction of hydrogen at the inlet of the microreactor.

Table 3: Flow and mass transfer parameters.

\begin{tabular}{|l|c|}
\hline \multicolumn{1}{|c|}{ Property } & Value \\
\hline Porosity of the bed, $\varepsilon$ & 0.40 \\
Water/ethanol molar ratio, Rwe & 3.3 \\
Catalyst density, $\rho_{\text {cat }}$ & $1.35 \times 10^{6} \mathrm{~g}_{\mathrm{cat}} / \mathrm{m}^{3}$ \\
Particle catalyst diameter, $\mathrm{d}_{\mathrm{p}}$ & $1.00 \times 10^{-5} \mathrm{~m}$ \\
Bed permeability, Kp & $1.19 \times 10^{-13} \mathrm{~m}^{2}$ \\
Temperature of the operation, $\mathrm{T}$ & $773 \mathrm{~K}$ \\
Pressure outlet channel, $\mathrm{P}_{\text {out }}$ & $100-500 \mathrm{kPa}$ \\
Microchannel height, $\mathrm{H}$ & $500 \mu \mathrm{m}$ \\
Microchannel width, $\mathrm{W}$ & $1800 \mu \mathrm{m}$ \\
Microchannel length, $\mathrm{L}$ & $3.0 \mathrm{~cm}$ \\
Membrane thickness, $\delta$ & $0.1-1.0 \mu \mathrm{m}$ \\
Velocity at the inlet, $\mathrm{u}_{0}$ & 0.01 and $0.03 \mathrm{~m} / \mathrm{s}$ \\
Space time, $\tau$ & $(0.75-2.24) \times 10^{5} \mathrm{~g}_{\text {cat }} \mathrm{s} / \mathrm{mol}$ \\
\hline
\end{tabular}

The local average ethanol conversion, denoted $\bar{\chi}_{\mathrm{e}}$, and the product yields, denoted $\overline{\mathrm{Y}}_{\mathrm{i}}$, were calculated according to Eqs. (18) and (20), respectively.

$\bar{\chi}_{\mathrm{e}}(\mathrm{x})=\frac{1}{\mathrm{H}} \int_{0}^{\mathrm{H}} \chi_{\mathrm{e}}(\mathrm{x}, \mathrm{y}) \mathrm{dy}$

in which

$$
\begin{aligned}
& \chi_{\mathrm{e}}(\mathrm{x}, \mathrm{y})=1-\left(\frac{\mathrm{u}}{\mathrm{u}_{\mathrm{o}}}\right)\left(\frac{\mathrm{P}}{\mathrm{P}_{\mathrm{o}}}\right)\left(\frac{\mathrm{Xe}}{\mathrm{Xe}_{\mathrm{o}}}\right) \\
& \bar{Y}_{\mathrm{i}}(\mathrm{x})=\frac{\mathrm{F}_{\mathrm{i}}}{\mathrm{F}_{\mathrm{eo}}}=\frac{\bar{X}_{\mathrm{i}} \mathrm{uP}}{\mathrm{Xe}_{\mathrm{o}} \mathrm{u}_{\mathrm{o}} \mathrm{P}_{\mathrm{o}}}
\end{aligned}
$$

where

$\bar{X}_{\mathrm{i}}(\mathrm{x})=\frac{1}{\mathrm{H}} \int_{0}^{\mathrm{H}} \mathrm{X}_{\mathrm{i}}(\mathrm{x}, \mathrm{y}) \mathrm{dy}$

$\mathrm{F}_{\mathrm{eo}}$ represents the molar flow rate of the ethanol at the inlet of the microchannel, $F_{i}$ the average molar flow rate of the product $i$ at a generic distance from the entrance of the microchannel, and $\bar{X}_{i}$ is the local average mole fraction of species $i$.

For the specific purpose of validating the numerical model, we compared it with the experimental results of Comas et al. (2004b). Thus, Figure 3 represents the comparison of measured yield and predicted values using the proposed reaction pathway and kinetic expressions and the membraneless microreactor approach. A good 
predictive ability of the numerical model for the product yields can be observed.

A discrepancy between the experimental conversion of the ethanol and the conversion predicted by the model is observed in this figure, mainly at the beginning of the reaction. The experimental results obtained by Comas et al. (2004b) show that ethanol is completely converted at very short contact times while the model predicts a different profile. The discrepancy between the experimental results and the values predicted by the model is due to the low kinetic coefficient proposed by Sun et al. (2005) and used in this paper for Reaction 2. According to Mas et al. (2006) ethanol is first completely converted into ethylene and acetaldehyde, which are subsequently converted into carbon oxides, methane and hydrogen. These reactions were not considered in the reaction pathway proposed in this paper, although Comas et al. (2004b) showed that, for a $\mathrm{Ni} / \mathrm{Al}_{2} \mathrm{O}_{3}$ catalyst, both ethylene and acetaldehyde are intermediate products formed from ethanol dehydration and dehydrogenation, respectively.

Nevertheless, the results validate our formulation of the numerical model, as well as the solution of the partial differential equations using the COMSOL Multiphysics ${ }^{\circledR}$ package and the assumptions made in terms of the reaction pathway and kinetic expressions.

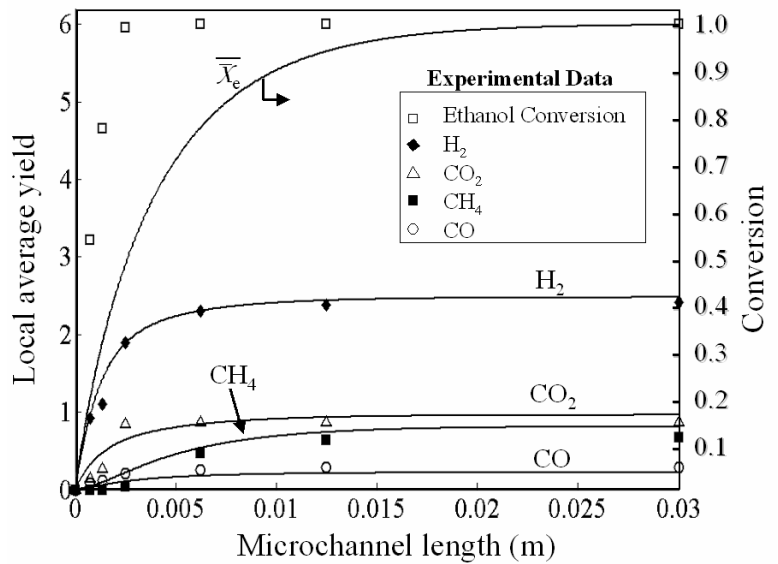

Figure 3: Experimental vs. model predicted yield and ethanol conversion values at $\mathrm{Rwe}=3.3, \mathrm{~T}=773 \mathrm{~K}$, $\mathrm{P}=100 \mathrm{kPa}, \mathrm{u}_{0}=0.03 \mathrm{~m} / \mathrm{s}, \tau=2.24 \times 10^{5} \mathrm{~g}_{\mathrm{cat}} \mathrm{s} / \mathrm{mol}_{\mathrm{EtOH}}$

The main advantage of the membrane microreactor is the improvement in conversion of the Reactions 3, 4 and 5 as a result of selective hydrogen removal. Due to the reaction rates given in Eqs. (1) through (4), the equilibrium is reached for a space time of approximately $7.5 \times 10^{4} \mathrm{~g}_{\mathrm{cat}} \mathrm{s} / \mathrm{mol}$, which is equivalent to a length of the microchannel of $0.01 \mathrm{~m}$. Thus, as shown in Figure 4, the effective microchannel length for a membraneless microreactor is about $0.01 \mathrm{~m}$, after which the hydrogen yield reaches a maximum value. In the membrane microreactor, with a $0.2 \mu \mathrm{m}$ membrane thickness, the effective microchannel length can be over $0.03 \mathrm{~m}$ since Reactions 3, 4 and 5 are shifted by hydrogen removal. Another advantage of the membrane microreactor is the production of pure hydrogen outside the membrane to supply a PEM fuel cell. In Figure 4 a lower hydrogen mole fraction throughout the membrane microreactor than in the membraneless microreactor is observed, indicating hydrogen removal from the reaction zone and thus the shift of Reactions 3, 4, and 5 towards those products. Thus, the removal of hydrogen from the reaction medium by its flow through the membrane dislocates the reaction towards the formation of greater yields of hydrogen. The figure also shows an increase in $\mathrm{CO}_{2}$ mole fraction and a lower $\mathrm{CH}_{4}$ mole fraction, which correspond to the higher amounts of hydrogen produced.

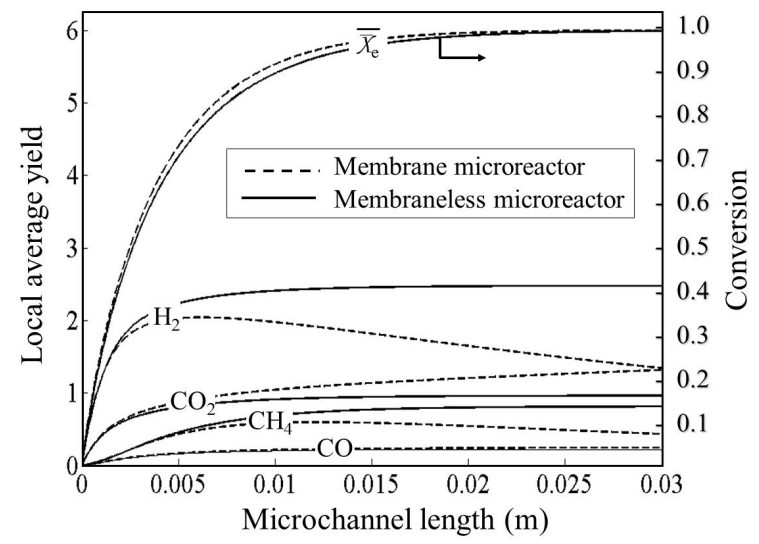

Figure 4: Comparison of local average yield and local average ethanol conversion between the membrane microreactor and the membraneless microreactor at Rwe $=3.3, \mathrm{~T}=773 \mathrm{~K}, \mathrm{P}_{\mathrm{o}}=100 \mathrm{kPa}$, $\mathrm{u}_{0}=0.03 \mathrm{~m} / \mathrm{s}, \tau=2.24 \times 10^{5} \mathrm{~g}_{\text {cat }} / \mathrm{mol}_{\mathrm{EtOH}}$ and $\delta=0.2 \mu \mathrm{m}$.

Hydrogen yields near 6 are obtained only for the reactor fitted with a $0.2 \mu \mathrm{m}$ palladium membrane, an inlet pressure $<300 \mathrm{kPa}$ and an inlet velocity of $0.01 \mathrm{~m} / \mathrm{s}$. For the conventional reactor hydrogen yields are lower than 2.50 (see Fig. 5). When a $0.2 \mu \mathrm{m}$ membrane thickness is used, the total hydrogen yield $\left(\mathrm{Y}_{\mathrm{h}, \text { total }}\right)$ increased from 2.50 to 4.05 if the membrane microreactor operated at a pressure of $100 \mathrm{kPa}$ and velocity of $0.03 \mathrm{~m} / \mathrm{s}$ in the microchannel 
entrance, as shown in the Figure 5; alternatively, if it operated at $\mathrm{P}=300 \mathrm{kPa}$ and $\mathrm{u}_{\mathrm{o}}=0.01 \mathrm{~m} / \mathrm{s}$ the total hydrogen yield increased to 5.13. This represents an increase of $105 \%$ over the membraneless microreactor in the equilibrium condition. The total hydrogen yield is calculated from Eq. (22):

$\mathrm{Y}_{\mathrm{h}, \text { total }}=\frac{\mathrm{F}_{\mathrm{h}, \text { total }}}{\mathrm{F}_{\mathrm{eo}}}$

where $F_{h, t o t a l}$ is the total molar flow of hydrogen in $\mathrm{mol} / \mathrm{s}$ and it can be estimated by

$$
\mathrm{F}_{\mathrm{h}, \text { total }}=\mathrm{W}\left[\int_{0}^{\mathrm{H}}\left(\left.\mathrm{N}_{\mathrm{h}}\right|_{\mathrm{x}=\mathrm{L}}\right) \mathrm{dy}+\int_{0}^{\mathrm{L}}\left(\left.\mathrm{N}_{\mathrm{h}}\right|_{\mathrm{y}=0}\right) \mathrm{dx}\right]
$$

The first integral in Eq. (23) refers to the molar flow of hydrogen that leaves the reformer in the outlet microchannel boundary, while the second integral refers to the molar flow of hydrogen across the membrane.

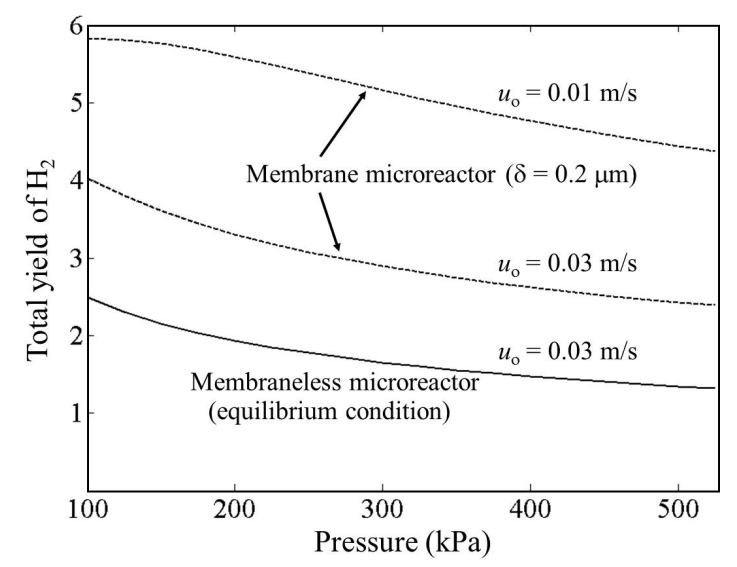

Figure 5: Total hydrogen yield $\left(\mathrm{Y}_{\mathrm{h}, \text { total }}\right)$ in function of the inlet pressure at $\mathrm{Rwe}=3.3, \mathrm{~T}=773 \mathrm{~K}$, $\mathrm{u}_{\mathrm{o}}=0.01$ or $0.03 \mathrm{~m} / \mathrm{s}$ and $\delta=0.2 \mu \mathrm{m}$ for the membrane microreactor.

The model used does not quantify the mass transfer rate gas-catalyst and, for the conventional reactor, the final composition is not affected by the inlet velocity. However, the intermediary composition along the microchannel is affected by the inlet velocity. On the contrary, as shown in Figure 5, for the membrane reactor, the outlet composition depends on the inlet velocity.

Although higher pressures improve the hydrogen permeability through the membrane, increased pressure has a negative influence on hydrogen formation. Figure 5 shows that higher pressure reduces the hydrogen yield for both the membraneless and membrane microreactors. This is caused by the expansion of the gas volume as the reactions proceed. Higher pressures worsen the equilibrium conditions of Reactions 4 and 5, increasing the methane yield in detriment to the hydrogen yield. Apart from this, high pressure leads to a higher concentration of reactants. This result is in agreement with other authors (Comas et al., 2004a; Song et al., 2005).

Figure 5 also shows that the reactant velocity at the microchannel entrance is important for the resulting total hydrogen yield of the membrane microreactor. A lower velocity leads to a higher yield, because the space time is higher too.

In Figure 6, the effect of the membrane thickness $(\delta)$ on the total hydrogen yield at different space times $(\tau=$ catalyst mass per molar flow rate of ethanol feed) is shown. It can be seen that by decreasing membrane thickness, mainly for values lower than $0.5 \mu \mathrm{m}$, the total hydrogen yield increases greatly for all space times analyzed. This means that membrane thickness has a significant effect on the performance of the microreactor. Thus, for a space time of $2.24 \times 10^{5} \mathrm{~g}_{\mathrm{cat}} \mathrm{s} / \mathrm{mol}$ and a $0.2 \mu \mathrm{m}$ membrane thickness, the total hydrogen yield reaches values as high as $5.13 \mathrm{~mol}$ of hydrogen per mol of ethanol feed, compared to a maximum yield of 6 considering complete ethanol steam reforming (Reaction 1).

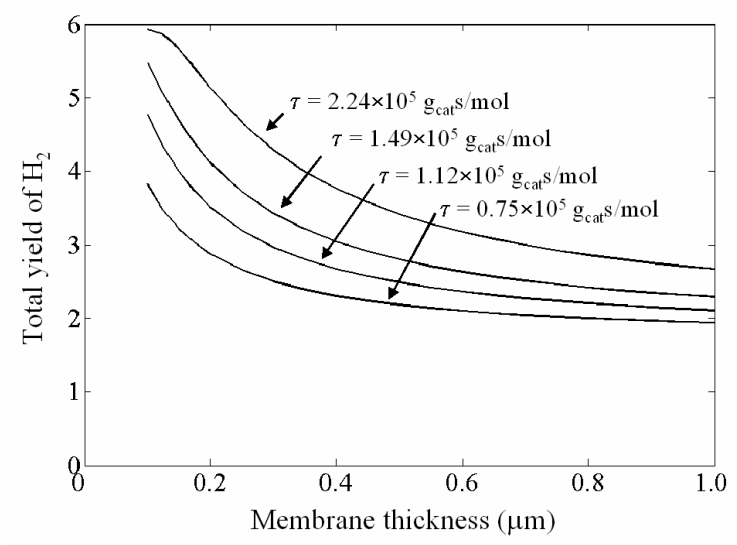

Figure 6: Influence of membrane thickness $(\delta)$ at different space times $(\tau)$ on the total hydrogen yield $\left(\mathrm{Y}_{\mathrm{h}, \text { total }}\right) . \mathrm{Rwe}=3.3, \mathrm{P}_{\mathrm{o}}=300 \mathrm{kPa}$ and $\mathrm{T}=773 \mathrm{~K}$.

Although thinner membranes are favorable, the mechanical resistance of the membrane will limit the minimum thickness. Four layers, viz., copper, aluminum, spin-on-glass (SOG) and palladium form the composite membrane. Copper, aluminum and SOG layers provide structural support for the 
palladium film (Karnik et al., 2003). In our model we consider that the copper, aluminum and SOG layers provide strength to the membrane, but offer no resistance to flow. Thus, the membrane was modeled only by the film of palladium. Besides the work of Karnik et al. (2003), other works such as Shi and Szpunar (2007) and Shi et al. (2009), indicate the possibility of fabricating Pd-based membranes of nanometric thicknesses that can withstand pressure differences over $300 \mathrm{kPa}$ and temperatures up to $773 \mathrm{~K}$. Because our interest focuses on a parametric theoretical study we were mostly concerned with the order of magnitude of the permeability parameter.

The pressure drop along the microchannel at two different pressures and a fixed space time of $2.24 \times 10^{5} \mathrm{~g}_{\text {cat }} \mathrm{s} / \mathrm{mol}$ is presented in Figure 7. It can be observed for both pressures (100 and $300 \mathrm{kPa})$ that the relative pressure drop decreases when the membrane microreactor is used instead of the membraneless microreactor. This is due to the fact that hydrogen removal contributes to the reduction of the axial velocity along the microchannel.

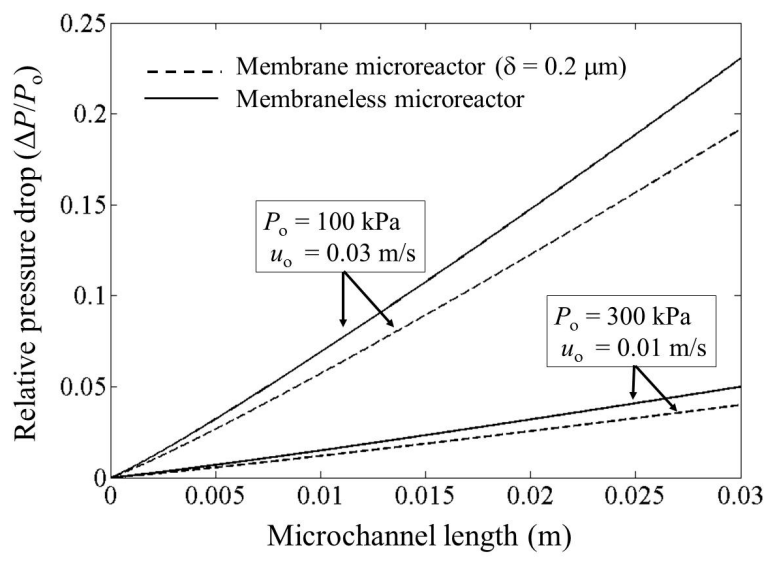

Figure 7: Pressure drop at a space time of $2.24 \times 10^{5} \mathrm{~g}_{\text {cat }} \mathrm{s} / \mathrm{mol}$, inlet pressure of 100 and $300 \mathrm{kPa}$, and $0.2 \mu \mathrm{m}$ membrane thickness for the membrane microreactor.

Figure 8 shows the hydrogen mole fraction profile $\left(\mathrm{X}_{\mathrm{h}}\right)$ along the microchannel (along the $\mathrm{x}$ axis, membrane at $y=0$ ). It can be seen that $X_{h}$ first increases and then decreases, indicating that hydrogen is produced and is subsequently partially removed through the membrane located at the microchannel inferior boundary.

The outlet flow rates of all species resulting from the membrane microreactor model at $\delta=0.2 \mu \mathrm{m}$, $\mathrm{u}_{\mathrm{o}}=0.01 \mathrm{~m} / \mathrm{s}$ and $\mathrm{P}_{\mathrm{o}}=300 \mathrm{kPa}$, are shown in Table 4 , in which the second and third column correspond to the cumulative values throughout the flow cross- section and the fourth column corresponds to the cumulative value along the reactor length. It can be noted that $83.9 \%$ from the produced hydrogen $\left(5.29 \times 10^{-7} \mathrm{~mol} / \mathrm{s}\right)$ permeates through the selective membrane, ensuring a source of high-purity hydrogen that can be directly utilized in a PEM fuel cell. The remaining $16.1 \%$ of the hydrogen of the reformate can be used for heat generation, which is required for the endothermic steam reforming.

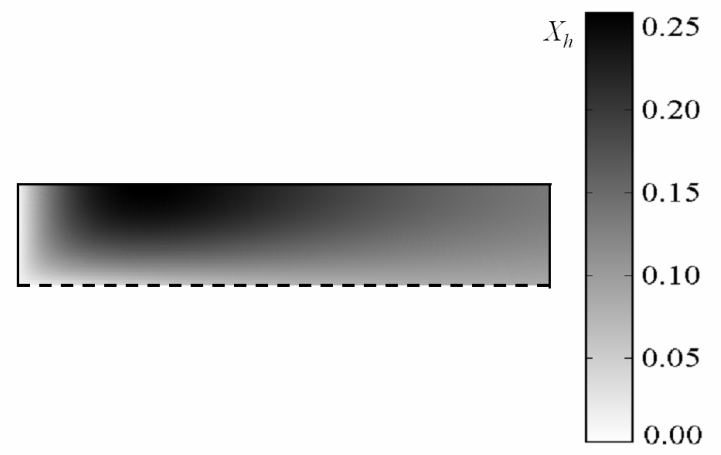

Figure 8: Mole fraction profile of hydrogen along the microchannel in the membrane microreactor at $\mathrm{T}=773 \mathrm{~K} ; \mathrm{u}_{\mathrm{o}}=0.01 \mathrm{~m} / \mathrm{s}\left(\tau=2.24 \times 10^{5} \mathrm{~g}_{\mathrm{cat}} / \mathrm{mol}_{\mathrm{EtOH}}\right)$ $\mathrm{P}_{0}=3 \mathrm{~atm}, \mathrm{Rwe}=3.3$ and $\delta=0.2 \mu \mathrm{m}$

Table 4: Predicted effluent cumulative flow rates along the reactor length or width resulting from the numerical model for the membrane microreactor with a $0.2 \mu \mathrm{m}$ membrane thickness, at $P_{0}=300 \mathrm{kPa}$ and $u_{0}=0.01 \mathrm{~m} / \mathrm{s}$

\begin{tabular}{|c|c|c|c|}
\hline $\begin{array}{c}\text { Total flow rates } \\
(\mathbf{m o l} / \mathbf{s})\end{array}$ & $\begin{array}{c}\text { Value at } \mathbf{x}=\mathbf{0}, \\
\mathbf{0} \leq \mathbf{y} \leq \mathbf{H}\end{array}$ & $\begin{array}{c}\text { Value at } \\
\mathbf{x}=\mathbf{L}, \mathbf{0} \leq \mathbf{y} \leq \mathbf{H}\end{array}$ & $\begin{array}{c}\text { Value at } \mathbf{y}=\mathbf{0}, \\
\mathbf{0} \leq \mathbf{x} \leq \mathbf{L}\end{array}$ \\
\hline $\mathrm{F}_{\mathrm{e}}$ & $1.03 \times 10^{-7}$ & $\cong 0$ & 0 \\
$\mathrm{~F}_{\mathrm{w}}$ & $3.40 \times 10^{-7}$ & $8.20 \times 10^{-8}$ & 0 \\
$\mathrm{~F}_{\mathrm{me}}$ & 0 & $1.83 \times 10^{-8}$ & 0 \\
$\mathrm{~F}_{\mathrm{m}}$ & 0 & $1.53 \times 10^{-8}$ & 0 \\
$\mathrm{~F}_{\mathrm{d}}$ & 0 & $1.73 \times 10^{-7}$ & 0 \\
$\mathrm{~F}_{\mathrm{h}}$ & $1.33 \times 10^{-9}$ & $8.53 \times 10^{-8}$ & $4.44 \times 10^{-7}$ \\
\hline
\end{tabular}

Our future work ont microreactors will include a study of non-isothermal conditions in the coupling of ethanol steam reforming with the catalytic oxidation of part of the effluent for generation of the thermalenergy required by the endothermic steam reforming. We are also modeling the coupling of ethanol steam reforming and the PEM fuel cell by a hydrogenpermselective membrane, in which the hydrogen produced in the reforming microchannel is consumed in situ by the PEM fuel cell. 


\section{CONCLUSION}

In this work, ethanol steam reforming was studied by a numerical comparison of a membrane microreactor with a membraneless microreactor. Model results showed that thin membranes $(<0.5 \mu \mathrm{m})$ increase the total hydrogen yield by up to $105 \%$ at temperature of $773 \mathrm{~K}$. In addition, more than $80 \%$ of the total hydrogen produced permeated across the membrane. Thus, membrane microreactors can be successfully applied to produce highpurity hydrogen for fuel cell systems, which can generate power for modern multifunctional portable devices.

The main contribution and novelty of this work is the conception of a membrane microreactor, in which both ethanol steam reforming and separation of hydrogen occur in one single microdevice. Potential advantages of this microreactor are its higher hydrogen production and elimination of the hydrogen purification stage for a PEM fuel cell, which requires $\mathrm{CO}$ concentrations below $20 \mathrm{ppm}$. Additionally, catalytic oxidation of the exhaust gases generate the thermal energy required for the endothermic steam reforming.

\section{NOMENCLATURE}

\begin{tabular}{|c|c|c|}
\hline $\mathcal{D}_{\mathrm{ef}, \mathrm{i}}$ & $\begin{array}{l}\text { effective concentration- } \\
\text { driven diffusion coefficient } \\
\text { of the specie i }\end{array}$ & $\mathrm{m}^{2} \mathrm{~s}^{-1}$ \\
\hline $\mathcal{D}_{\mathrm{i}}$ & $\begin{array}{l}\text { diffusion coefficient of the } \\
\text { specie } i \text { in the } \\
\text { multicomponent mixture }\end{array}$ & $\mathrm{m}^{2} \mathrm{~s}^{-1}$ \\
\hline $\mathrm{D}_{\mathrm{ik}}$ & $\begin{array}{l}\text { binary diffusivity for the } \\
\text { pair i-k in the } \\
\text { multicomponent system }\end{array}$ & $\mathrm{m}^{2} \mathrm{~s}^{-1}$ \\
\hline$d_{p}$ & catalyst particles diameter & \\
\hline $\mathrm{F}_{\mathrm{h}, \text { total }}$ & $\begin{array}{l}\text { total molar flow rate of } \\
\text { hydrogen }\end{array}$ & $\mathrm{mol} \mathrm{s}^{-1}$ \\
\hline Fi & $\begin{array}{l}\text { molar flow rate of species i } \\
\text { at a generic distance from } \\
\text { the entrance of the } \\
\text { microchannel }\end{array}$ & $\mathrm{mol} \mathrm{s}^{-1}$ \\
\hline $\mathrm{F}_{\text {io }}$ & $\begin{array}{l}\text { molar flow rate of the } \\
\text { species } i \text { at the inlet of the } \\
\text { microchannel }\end{array}$ & $\mathrm{mol} \mathrm{s}^{-1}$ \\
\hline $\mathrm{H}$ & channel height & $\mathrm{m}$ \\
\hline K & Boltzmann constant & $\mathrm{J} \mathrm{K}^{-1}$ \\
\hline $\mathrm{k}_{\mathrm{j}}$ & $\begin{array}{l}\text { reaction rate constant of the } \\
\mathrm{j}^{\text {th }} \text { reaction }\end{array}$ & \\
\hline $\mathrm{K}_{\mathrm{j}}$ & $\begin{array}{l}\text { equilibrium constant of the } \\
j^{\text {th }} \text { reaction }\end{array}$ & \\
\hline
\end{tabular}

$\mathrm{k}_{\mathrm{p}}$

$\mathrm{K}_{\mathrm{p}}$

$\mathrm{L}$

$\mathrm{M}_{\mathrm{i}}$

$\mathrm{N}_{\mathrm{i}}$

$\mathrm{N}_{\mathrm{i}}$

$\mathrm{P}$

microchannel

$\mathrm{Pe} \quad$ Peclet number

$\mathrm{P}_{\mathrm{h} \text {,outside }}$ partial pressure of the hydrogen outside of the membrane

$\mathrm{P}_{\text {out }} \quad$ pressure at the outlet of the microchannel

$\mathrm{R}_{\mathrm{g}} \quad$ universal gas constant

$r_{j} \quad$ reaction rate of the $j^{\text {th }}$

reaction

$\mathrm{T}$ temperature

$\mathrm{u} \quad$ component of the velocity vector in the $\mathrm{x}$ direction

u fluid flow velocity vector

$\mathrm{u}_{\mathrm{o}} \quad$ fluid flow velocity at the inlet of the microchannel

$\mathrm{v}$ component of the velocity vector in the y direction

$\mathrm{v}_{\mathrm{p}}$ velocity of the fluid as it diffuses through the membrane

W channel width

$\mathrm{w}_{\text {cat }}$

$\mathrm{x}, \mathrm{y}$

$X_{i}$

$\overline{\mathrm{X}}_{\mathrm{i}}$

catalyst mass

cartesian coordinates

mole fraction of component $\mathrm{i}$

$\bar{X}_{\mathrm{i}}(\mathrm{x})=$ local average mole

fraction of species $i$

mole fraction of component

$i$ at the inlet of the

microchannel

$\mathrm{Y}_{\mathrm{h}, \text { total }}$

$\bar{Y}_{\mathrm{i}}$

total hydrogen yield

$\overline{\mathrm{Y}}_{\mathrm{i}}(\mathrm{x})=\mathrm{F}_{\mathrm{i}} / \mathrm{F}_{\mathrm{e} 0}=$ local

average products yields $\mathrm{mol} \mathrm{m} \mathrm{m}^{-2} \mathrm{~Pa}^{-1}$

$\mathrm{mol} \mathrm{m} \mathrm{m}^{-2} \mathrm{~Pa}^{-1}$

$\mathrm{kg} \mathrm{mol}^{-1}$

$\mathrm{mol} \mathrm{m} \mathrm{m}^{-2}$

$\mathrm{Pa}$

$\mathrm{Pa}$

$(-)$

$\mathrm{Pa}$

$\mathrm{Pa}$

$8.314 \mathrm{~J} \mathrm{~mol}^{-1} \mathrm{~K}^{-1}$ $\mathrm{mol} \mathrm{s}^{-1} \mathrm{~g}_{\text {cat }}^{-1}$

K

$\mathrm{m} \mathrm{s}^{-1}$

$\mathrm{m} \mathrm{s}^{-1}$

$\mathrm{m} \mathrm{s}^{-1}$

$\mathrm{m} \mathrm{s}^{-1}$

$\mathrm{m} \mathrm{s}^{-1}$

$\mathrm{m}$

g

$\mathrm{m}$

$(-)$

$(-)$

$(-)$

$(-)$

\section{Greeks Letters}

$\delta \quad$ membrane thickness

$\mathrm{m}$

porosity of the bed

$(-)$

$\varepsilon_{\mathrm{ik}} \quad$ maximum attractive energy

$\mathrm{J}$ between molecule $i$ and molecule $\mathrm{k}$

$\mu \quad$ viscosity $\mathrm{kg} \mathrm{m}^{-1} \mathrm{~s}^{-1}$ 


\begin{tabular}{|c|c|c|}
\hline 366 & & M. de-Souza, G. N \\
\hline$\mu_{\mathrm{i}}$ & $\begin{array}{l}\text { viscosity of an individual } \\
\text { component }\end{array}$ & $\mathrm{kg} \mathrm{m}^{-1} \mathrm{~s}^{-1}$ \\
\hline$v_{\mathrm{ij}}$ & $\begin{array}{l}\text { stoichiometric coefficient of } \\
\text { component } \mathrm{i} \text { in } \mathrm{j}^{\text {th }} \text { reaction }\end{array}$ & \\
\hline$\rho_{\text {cat }}$ & $\begin{array}{l}\text { catalyst mass per unit of } \\
\text { volume, }\end{array}$ & $\mathrm{kg} \mathrm{m}{ }^{-3}$ \\
\hline$\sigma_{\mathrm{ik}}$ & collision diameter & $\AA$ \\
\hline$\tau$ & space time & $\mathrm{g}_{\text {cat }} \mathrm{s} \mathrm{mol} \mathrm{mol}^{-1}$ \\
\hline$\tau_{\mathrm{ik}}$ & dimensionless temperature & $(-)$ \\
\hline$\Phi_{\mathrm{ik}}$ & Chapman-Enskog parameter & $(-)$ \\
\hline$\Omega_{\mathrm{ik}}$ & collision integral & $(-)$ \\
\hline $\bar{\chi}_{\mathrm{e}}$ & $\begin{array}{l}\bar{\chi}_{\mathrm{e}}(\mathrm{x})=\text { local average } \\
\text { ethanol conversion }\end{array}$ & $(-)$ \\
\hline
\end{tabular}

\section{Subscripts}

$\begin{array}{ll}\text { d } & \mathrm{CO} 2 \text { (carbon dioxide) } \\ \text { e } & \text { EtOH }=\mathrm{C}_{2} \mathrm{H}_{5} \mathrm{OH} \text { (ethanol) } \\ \text { h } & \mathrm{H}_{2} \text { (hydrogen gas) } \\ \mathrm{i}, \mathrm{k} & \text { species in multicomponent } \\ \mathrm{j} & \text { systems } \\ \mathrm{m} & \text { reaction } \\ \text { me } & \mathrm{CO} \text { (carbon monoxide) } \\ \text { w } & \mathrm{CH} \text { (methane) }\end{array}$

\section{REFERENCES}

Aicher, T., Full, J., Schaadt, A., A portable fuel processor for hydrogen production from ethanol in a $250 \mathrm{~W}_{\text {el }}$ fuel cell system. Int. J. Hydrogen Energy, 37, pp. 8006-15 (2009).

Alfadhel, A. A., Kothare, M. V., Microfluidic modeling and simulation of flow in membrane microreactors. Chem. Eng. Sci., 60, pp. 2911-26 (2005).

Aravamudhan, S., Rahman, A. R. A., Bhansali, S., Porous silicon based orientation independent selfpriming micro direct ethanol fuel cell. Sens. Actuators, A, 123-4, pp. 497-504 (2005).

Assaf, E. M., Jesus, C. D. F., Assaf, J. M. Mathematical modeling of methane steam reforming in a membrane reactor: an isothermic model. Braz. J. Chem. Eng. 15, no. 2, June (1998).

Bird, R. B., Stewart, W. E., Lightfoot, E. N., Fenômenos de Transporte. $2^{\text {nd }}$ Ed., LTC, Rio de Janeiro (2004). (In Portuguese).

Comas, J., Laborde, M., Amadeo, N., Thermodynamic analysis of hydrogen production from ethanol using $\mathrm{CaO}$ as a $\mathrm{CO}_{2}$ sorbent. J. Power Sources, 138, pp. 61-67 (2004a).
Comas, J., Mariño, F., Laborde, M., Amadeo, N., Bio-ethanol steam reforming on $\mathrm{Ni} / \mathrm{Al}_{2} \mathrm{O}_{3}$ catalyst. Chem. Eng. J., 98, pp. 61-8 (2004b).

Delsman, E. R., Microstructured Reactors for a Portable Hydrogen Production Unit. Ph.D Thesis, Technische Universiteit Eindhoven, Eindhoven, Netherlands (2005).

Deshmukh, S. R., Vlachos, D. G., Effect of flow configuration on the operation of coupled combustor/reformer microdevices for hydrogen production. Chem. Eng. Sci., 60, pp. 5718-28 (2005).

Dixon, A. G., Correlations for wall and particle shape effects on fixed bed bulk voidage. Can. J. Chem. Eng., 66, 705 (1988).

Falco, M., Gallucci, F., Ethanol steam reforming heated up by molten salt CSP: Reactor assessment. Int. J. Hydrogen Energy, 35, pp. 3463-71 (2010).

Fatsikostas, A. N., Verykios, X. E., Reaction network of steam reforming of ethanol over Nibased catalysts. J. Catal., 225, pp. 439-52 (2004).

Haryanto, A., Fernando, S., Murali, N., Adhikari, S., Current status of hydrogen production techniques by steam reforming of ethanol: A review. Energ. Fuel, 19, pp. 2098-106 (2005).

Hotza, D., Costa, J. C. D., Fuel cells development and hydrogen production from renewable resources in Brazil. Int. J. Hydrogen Energy, 33, pp. 4915-35 (2008).

Hu, J., Wang, Y., Vanderwiel, D., Chin, C., Palo, D., Rozmiarek, R., Dagle, R., Cao, J., Holladay, J., Baker, E., Fuel processing for portable power applications. Chem. Eng. J., 93, pp. 55-60 (2003).

Iulianelli, A., Longo, T., Liguori, S., Seelam, P. K., Keiski, R. L., Basile, A., Oxidative steam reforming of ethanol over $\mathrm{Ru}-\mathrm{Al}_{2} \mathrm{O}_{3}$ catalyst in a dense $\mathrm{Pd}-\mathrm{Ag}$ membrane reactor to produce hydrogen for PEM fuel cells. Int. J. Hydrogen Energy, 34, pp. 8558-65 (2009).

Karnik, S. V., Hatalis, M. K., Kothare, M. V., Towards a palladium micro-membrane for the water gas shift reaction: Microfabrication approach and hydrogen purification results. J. Microelectromechanical Sys., 12, pp. 93-100 (2003).

Kawamura, Y., Ogura, N., Yamamoto, T., Igarashi, A., A miniaturized methanol reformer with Sibased microreactor for a small PEMFC. Chem. Eng. Sci., 61, pp. 1092-101 (2006).

Kim, G. Y., Mayor, J. R., Ni, J., Parametric study of microreactor design for water gas shift reactor using an integrated reaction and heat exchange model. Chem. Eng. J., 110, pp. 1-10 (2005). 
Klouz, V., Fierro, V., Denton, P., Katz, H., Lisse, J. P., Bouvot-Mauduit, S., Mirodados, C., Ethanol reforming for hydrogen production in a hybrid electric vehicle: Process optimization. J. Power Sources, 105, pp. 26-34 (2002).

Lee, D. K., Baek, I. H., Yoon, W. L., A simulation study for the hybrid reaction of methane steam reforming and in situ $\mathrm{CO}_{2}$ removal in a moving bed reactor of a catalyst admixed with a $\mathrm{CaO}$ based $\mathrm{CO}_{2}$ acceptor for $\mathrm{H}_{2}$ production. Int. J. Hydrogen Energy, 31, pp. 649-57 (2006).

Löwe, H., Ehrfeld, W., State-of-art in microreaction technology: Concepts, manufacturing and applications. Electrochim. Acta, 44, pp. 3679-89 (1999).

Mariño, F., Boveri, M., Baronetti, G., Laborde, M., Hydrogen production from steam reforming bioethanol using $\mathrm{Cu} / \mathrm{Ni} / \mathrm{K} / \gamma-\mathrm{Al}_{2} \mathrm{O}_{3}$ catalysts Effect of $\mathrm{Ni}$. Int. J. Hydrogen Energy, 26, pp. 665-8 (2001).

Mas, V., Kipreos, R., Amadeo, N., Laborde, M., Thermodynamic analysis of ethanol/water system with the stoichiometric method. Int. J. Hydrogen Energy, 31, pp. 21-8 (2006).

Neufeld, P. D., Jansen, A. R., Aziz, R. A., Empirical equations to calculate 16 of the transport collision integrals $\Omega^{(1, \mathrm{~s})^{*}}$ for the Lennard-Jones (12-6) potential. J. Chem. Phys. 57, pp. 1100-1102 (1972).

Palo, D. R., Holladay, J. D., Rozmiarek, R. T., Guzman-Leong, C. E., Wang, Y., Hu, J., Chin, Y., Dagle, R. A., Baker, E. G., Development of a soldier-portable fuel cell power system Part I: A bread-board methanol fuel processor. J. Power Sources, 108, pp. 28-34 (2002).

Pattekar, A. V., Kothare, M. V., Modeling, design and control of silicon based microchemical systems. Ann. Meet. AIChE, Indianapolis (2002).

Pattekar, A. V., Kothare, M. V., A microreactor for hydrogen production in micro fuel cell applications. J. Microelectromech. S., 13, pp. 7-18 (2004).

Pattekar, A. V., Kothare, M. V., Karnik, S. V., Hatalis, M. K., A microreactor for in-situ hydrogen production by catalytic methanol reforming. $5^{\text {th }}$ IMRET, Strasbourg (2001).

Perry, R. H., Green, D. W., Maloney, J. O., Perry's Chemical Engineers' Handbook. $7^{\text {th }}$ Ed., McGraw Hill, New York (1997).

Shi, Z., Szpunar, J. A., Synthesis of an ultra-thin palladium membrane for hydrogen extraction. Rev. Adv. Mater. Sci., 15, pp. 1-9 (2007).
Shi, Z., Szpunar, J. A., Wu, S., Design and synthesis of thin palladium membranes on porous metal substrate for hydrogen extraction. J. Phys. Conf. Ser., 165012062 (2009).

Song, H., Zhang, L., Watson, R. B., Braden, D., Ozkan, U. S., Investigation of bio-ethanol steam reforming over cobalt-based catalysts. Catal. Today, 145, pp. 502-14 (2007).

Sordi, A., Silva, E. P., Milanez, L. F., Lobkov, D. D., Souza, S. N. M., Hydrogen from biomass gas steam reforming for low temperature fuel cell: Energy and exergy analysis. Braz. J. Chem. Eng., 26, pp. 159-169 (2009).

Sun, J., Qiu, X. P., Wu, F., Zhu, W. T., $\mathrm{H}_{2}$ from steam reforming of ethanol at low temperature over $\mathrm{Ni} / \mathrm{Y}_{2} \mathrm{O}_{3}, \mathrm{Ni} / \mathrm{La}_{2} \mathrm{O}_{3}, \mathrm{Ni} / \mathrm{Al}_{2} \mathrm{O}_{3}$ catalysts for fuel-cell application. Int. J. Hydrogen Energy, 30, pp. 437-45 (2005).

Terazaki, T., Nomura, M., Takeyama, K., Nakamura, O., Yamamoto, T., Development of multi-layered microreactor with methanol reformer for small PEMFC. J. Power Sources, 145, pp. 691-696 (2005).

Therdthianwong, A., Sakulkoakiet, T., Therdthianwong, S., Hydrogen production by catalytic ethanol steam reforming. Science Asia, 27, pp. 193-8 (2001).

Trimm, D. L., Design of Industrial Catalysts. Elsevier Scientific Publishing Company, New York (1980).

Vaidya, P. D., Rodrigues, A. E., Insight into steam reforming of ethanol to produce hydrogen for fuel cells. Chem. Eng. J., 117, pp. 39-49 (2006).

Wang, Y. N., Rodrigues, A. E., Hydrogen production from steam methane reforming coupled with in situ $\mathrm{CO}_{2}$ capture: Conceptual parametric study. Fuel, 84, pp. 1778-89 (2005).

Winter, C. J., Hydrogen energy - abundant, efficient, clean: A debate over the energy-system-ofchange. Int. J. Hydrogen Energy, 34, S1-S52 (2009).

Wörz, O., Jäckel, K. P., Richter, Th., Wolf, A., Microreactors, a new efficient tool for optimum reactor design. Chem. Eng. Sci., 56, pp. 1029-33 (2001).

Xu, J. G., Froment, G. F., Methane steam reforming, methanation and water-gas shift: I. Intrinsic kinetics. AIChE J., 35, 88-96 (1989)

Yao, S., Tang, X., Hsieh, C., Alyousef, Y., Vladimer, M., Fedder, G. K., Amon, C. H., Micro-electromechanical systems (MEMS)-based micro-scale direct methanol fuel cell development. Energy, 31, pp. 636-49 (2006). 